\title{
Working the graveyard shift Reflections of an evening/weekend librarian
}

I t's 3:00 on a weekday afternoon. While most of you are winding down your day, maybe looking to snag a piece of chocolate for one last burst of energy until it is time to go home, my workday is just beginning. For the past eight years, I have been the evening/weekend supervisor at the St. Joseph's College Library in Brooklyn, New York. In today's world, where technology and a changing student population is remaking the library into a 24/7 information center, my experiences working the graveyard shift are instructive as we contemplate the future of library services, and of librarianship itself.

With more nontraditional students entering college, most of whom take classes in the evenings and on weekends, academic libraries are now hubs of activity literally from sun-up to sundown, seven days a week. The needs of these nontraditional students diverge significantly from that of the typical arts and sciences student, the most glaring difference being the ability to navigate technology.

While your traditional college student can typically handle the ins and outs of technology without a great deal of assistance, many nontraditional students have difficulties with even the simplest tasks, including sending and accessing e-mail (attaching a document to a flash drive and e-mailing it seems to particularly bedevil them), printing, using Word, Excel, Powerpoint, etc.

However, while day students have a fully staffed library to service their needs, this is often not the case for evening and weekend students. At St. Joseph's College, along with a student worker, I am the only library employee in the evenings and on the weekends. On more occasions than I care to think about, I have been the only professional staff member helping a library full of frustrated students. The famous Rudyard Kipling lines, "If you can keep your head when all about you / Are losing theirs and blaming it on you" frequently come to mind during these times.

Unfortunately, administrators often do not realize that the library is just as hectic at night as it is as during the day. This is understandable, as most administrators work 9 to 5-type hours, and don't experience first-hand what the library is like at night and on the weekends.

As an example, a few years ago, I had a meeting with an IT supervisor about having a technology worker in the library in the evenings. The supervisor, who worked days, did not understand why there was a need for a worker at night when the library was presumably less busy, especially when there was no need for one during the day. I had to explain that not only was the library just as crowded at night as it was during the day, but that the evening students needed far more technological assistance than their daytime counterparts.

It is important, then, for evening/weekend librarians to communicate to their supervisors how busy the library gets. While you shouldn't expect to suddenly have a full complement of staff at night, you can at least raise awareness, which is a meaningful first step.

Robert Lasner is evening/weekend supervisor/ instruction coordinator at St. Joseph's College's McEntegart Hall Library, e-mail: rlasner@sjcny.edu C 2014 Robert Lasner 
... along with a student worker, I am the only library employee in the evenings and on the weekends. On more occasions than I care to think about, I have been the only professional staff member helping a library full of frustrated students.

Working the graveyard shift can also be isolating, both from professional colleagues and the wider campus community. It can be difficult to serve on college-wide committees, which generally meet during the day, as well as to attend lectures, talks, and other campus events. I serve on one committee, which luckily meets late in the afternoon, but I regularly miss authors and other speakers who visit the campus. Even if they are speaking at night, I can't go, because I am working.

My schedule also affects interactions with my fellow librarians, as I am often not part of the informal conversations that occur during the course of a workday, leaving me out of everything from discussions of professional issues to personal chit-chat to general gripe sessions.

It also takes me longer to get to know new library staff_-on occasion, individuals have come and gone without me having even met them. An evening/weekend librarian has to be very proactive in engaging with colleagues in order to develop and maintain personal and professional relationships. You always have to reach out, in person preferably, but via e-mail or other forms of communication if that is the only way to keep in touch with your colleagues. Fortunately, my current director speaks to me nearly every day, which helps me stay in the loop.

If your director isn't a communicator, you must take the lead in establishing a consistent dialogue. You should suggest regular meetings, at least twice a week, to keep the lines of communication open. At the very least, you should e-mail your director regular updates about what you are doing and what is happening in the library, to keep him or her in the loop.

Despite the unusual circumstances of my job, there are many things I enjoy about the graveyard shift. It is quite satisfying to work with nontraditional students, who have often made substantial personal sacrifices to attend school. I also enjoy the "Wild West" atmosphere of working at night and on the weekend, where improvising creative solutions to unusual problems with limited support staff is the norm. As the library is often the only academic location on campus open after hours, everything from fixing the copier and printer to explaining to a student why he or she can't register for a class because of a hold that cannot be taken off until the next day, becomes my responsibility. In these instances, the ability to understand the basic workings of several college departments-from IT to the registrar's office-is required.

On a personal level, there are many nice perks to my job, including sleeping in on a cold, rainy morning, and to not have to be on a crowded New York subway train during rush hour. Best of all, since my son was born three years ago, I have been able to spend time with him as a "stay-athome" dad, which I would not have been able to do if I worked regular hours. Like anything, working nights and weekends offers rewards even among its challenges.

In closing, working the graveyard shift reminds me of what Charles Foster Kane says to Mr. Carter, the old, antiquated newspaper editor, when he takes over the New York Herald in Citizen Kane, "That's one of the things I think must be changed, Mr. Carter. The news goes on for twenty-four hours a day."

With nontraditional students becoming more prevalent, and technology assuming a greater role in our lives, the college library, like our world, is quickly transforming into-to paraphrase Charlie Kane-a place that goes on for 24 days a day, making the evening/weekend librarian more essential than ever. $\boldsymbol{n}$ 